\title{
An Analysis of The Existence Level of West Javanese Traditional Beverages as Sundanese Cultural Heritage
}

\author{
Nadya Nuansa Ramadhany, Ridwan Iskandar, Agus Sudono \\ University of Education, Jl. Dr. Setiabudhi No. 229, Bandung 40154, Indonesia \\ Author.E-mail: nadyanr@student.upi.edu (Nadya Nuansa Ramadhany)
}

\begin{abstract}
This research focuses on West Javanese traditional beverages. West Javanese traditional beverages are very varied in types. There are two main types of West Javanese traditional beverages in Bandung, namely hot and cold beverages. At present, the existence of traditional beverages is less popular compared to foreign beverages, such as Thai tea, boba milk tea, and so on. A real action in maintaining and preserving these traditional West Javanese beverages is a need. Therefore, this research aims to evaluate the exsistence level or popularity of traditional West Javanese beverages in Bandung, as a contribution to the literature on traditional beverages and a real action in presereving the beverages. This research employs a mix method research, with data collection techniques, using in-depth interviews, questionnaires, literature studies, and documentation studies. The purpose of this study is to determine whether traditional West Javanese beverages still exist in society, considering that in this era of globalization, food trends and people's tastes continue to change from time to time along with the influence of foreign cultures in Indonesia. The results of this study indicate that each type of traditional West Javanese beverages are at different level of existence, and the least exist beverages in society must be increased to avoid extinction.
\end{abstract}

Keywords: $\quad$ Existence; Traditional beverages; Culture; West Java.

* Corresponding

First Received:

Revised:

June 2020

July 2020

Accepted:

July 2020

Final Proof Received:

Published:

November 2020

December 2020 


\section{Introduction}

Indonesia is rich in various ethnic groups, customs, cultural arts, and languages, which are sources for the development of creativity. The wider the cultural diversity of a nation, the greater the potential for creativity to progress and develop in global competition. One of the provinces that is rich in tourism potential is West Java. West Java is a province in Indonesia with abundant tourism objects, both natural and artificial tourisms. As one of the most famous cities in West Java and in Indonesia, Bandung is always crowded with tourists.

The city of Bandung is well known for its nickname as a culinary city. Culinary tourism is a tour that deliberately explores food including consumption, preparation and presentation of food, cuisine, or food style (Long, 2004). West Java, especially Bandung, is currently designated as a culinary tourism destination. Gastronomic tourism is considered to need more attention from the government and society. According to Taqwani (2012), gastronomy is the study of the relationship between culture and food which studies cultural components with food as the center and in the form of culture. Culture and gastronomy are formed from the results of cultivation, which occurs in all agricultural activities, so as to produce the color, aroma, and taste of a food, which can be traced its origin from the environment the raw material came from.

Sundanese and their language are two things that are identical and inherent in the people of West Java. Rouffaer in the book entitled Dinas Kebudayaan dan Pariwisata (2011) states that the Sundanese are an ethnic group originating from the western part of Java Island, Indonesia, with the term Tatar Pasundan which covers the provinces of West Java, Central Java, Lampung, Jakarta and Banten. Currently, Sundanese gastronomy, which is located in Bandung, has a variety of amounts, namely 303 recipes with various types of food, and 12 of them are beverages (Turgarini, 2018).

Traditional beverages are drinks that are processed traditionally, and are passed down from generation to generation based on ancestral recipes, local beliefs, both magically and in local knowledge (Sunaryo, 2015). Aaccording to Tugarini (2018), there were twelve traditional West Javanese beverage menus, namely bandrek, bajigur, sakoteng, es bojong, es cingcau, es cuing, es serut, tjampolay syrup, es goyobod, es peuyeum kalapa muda, es pala, and lahang. Warm traditional beverages are bandrek, bajigur, and sakoteng, while traditional cold beverages include es bojong, es cingcau, es cuing, es parut, tjampolay syrup, es goyobod.

As time goes by, traditional beverages are now starting to be marginalized due to the strike of foreign culture in beverages, which are considered simpler and more delicious, and flooding the Indonesian market. Currently, Indonesians prefer to buy foreign beverage products which are not necessarily good for the body as these beverage products contain a lot of chemicals which are not good for the body.

Based on the results of pre-research conducted by researchers, the majority of respondents know that bajigur is a traditional beverage in West Java. In total of $74 \%$ of respondents know that bajigur is a traditional West Javanese beverage, then followed by bandrek at $71 \%$, es cendol $42 \%$, es cingcau $16 \%$, sakoteng $9.6 \%$, and lahang 3.2\%. Meanwhile, respondents did not mention other traditional West Javanese beverages. It is found that $35 \%$ of respondents often consume Thai tea, $32 \%$ frequently consume bajigur.

Thus, it can be seen that most people, especially in Bandung, prefer foreign beverages rather than the traditional ones. Furthermore, many of them still clueless about the difference between traditional beverages and other beverages. Bajigur is one of the best-known West Javanese 
traditional beverages. However, other traditional West Javanese beverages are still unnoticeable, such as es cuing, es serut, and tjampolay syrup. Thus, it is important to introduce the beverages as an effort to preserve them. In addition, based on the results of the pre-research, the researchers considered that more research on traditional beverages need to be carried out.

\section{Literature Review}

\subsection{Sundanese culture}

According to Ekadjati (1993) Sundanese culture refers to what lives, grows, and develops among the Sundanese people, who generally live in Sundanese land. Sundanese culture has characteristics that differentiate it from other cultures. Hufad (2005) reported that Sundanese people are known as friendly and religious individuals. This is aligned with the Sundanese motto, namely silih asih, silih asah and silih asuh which means loving one another, improving oneself (through education and knowledge), and protecting one another.

According to Kalsum (2010), it is estimated that the staple food of ancient Sundanese was hui or any kind of tubers. It can be seen from several traditional ceremonies, such as in Tingkeban ritual, or Sundanese baby shower, various aseupan (steamed food) are derived from tubers. Tubers that are easily uprooted from the ground symbolize a hope that the childbirth process will go well. To complete the staple foods and snacks served, there are usually traditional beverages as well. The warm beverages that are usually served are bandrek, bajigur, sakoteng, while the cold beverages are es bojong, es cingcau, es cuing, es serut, tjampolai syrup, and es goyobod.

According to Ningsih (2020), it is need to identify and preserve the traditional Sundaneses food and beverage that can be a Sundanese gastronomy tourism attraction.

\subsection{Traditional Beverages}

Sunaryo (2015) explained that traditional beverages are beverages that are traditionally processed and passed down from generation to generation based on ancestral recipes, local belief customs, both magically and in local knowledge.

West Java has a variety of traditional beverages with distinctive taste. Beverages are materials that are needed by living things for their survival. As for consumption, the quality of the beverage must be guaranteed to avoid disease, especially beverages that contain food additives, such as artificial sweeteners or preservatives.

Accordingly, in general, traditional beverages' raw materials come from the area where they are served and processed traditionally.

\subsection{The Variety of Traditional West Javanese Beverages}

Turgarini (2018) stated that the variety of Sundanese gastronomy in Bandung is 303 recipes with various types of food and beverages and 12 of them are beverages. There are twelve types of Sundanese traditional beverages, namely bandrek, bajigur, sakoteng, es bojong, es cingcau, es cuing, es serut, tjampolay syrup, goyobod, es peuyeum kalapa muda, es pala, and lahang.

\subsection{Existence Level}

\subsubsection{Definition of Existence Level}

Zaprulkhan (2012) stated that existence is derived from the Latin language, "existere" which means keeping a distance. In other words, only humans can distance themselves from their existence and question it. Therefore, existence means the presence of objects and humans. Something or someone is required to take a distance to get the meaning of the word exist or existence. 


\subsubsection{The Existence Level of West Javanese Traditional Beverages}

There are indicators of the level of existence of a culinary product according to Kerly (2018), namely dietary habits, product availability, product marketing, and also serving time.

a. Dietary habit

According to Notoatmodjo (2007), diet is a person's response to food as one of the main needs in life. This behavior includes knowledge, perceptions, attitudes and practices towards food and the elements it contains (nutrients), food processing, and so on.

b. Product availability

One of the factors that influence the consumer purchasing interest according to Kotler (2005) is the product availability factor. The more appropriate the product is to what has been scheduled in its availability, the more it will affect the consumer's purchasing intensity.

\section{c. Product marketing}

Marketing is a social process which involves individuals and groups to obtain what the people need through creation, offering and exchange of products and services with other parties (Keller, 2006).

d. Serving Time

Traditional beverage is a symbol of the cultural tradition of a region in preserving the customs of the ancestors. In this case, the Sundanese or West Javanese people are place a high value on their principles and culture from a social and religious perspective. West Javanese have a habit of gathering or ririungan, in which they usually provide warm beverages, such as bandrek, bajigur, and sakoteng. Since the weather in several cities in West Java is cold, it is perfect to enjoy a warm beverage. On the other hand, several cities in West Java have hot weather, so enjoying es cendol, es cuing ice, es peuyeum kalapa muda, es goyobod, es serut, es bojong, es cingcau, es pala, and lahang.

\section{Research Methods}

Research methodology is the science of methods, the study of methods, especially scientific methods, namely the methods used to pursue knowledge of a science field (The Lian Gie in Suharyono and Amien, 2013). According to Arikunto (2002), quantitative research is different from qualitative. In qualitative research, researchers do not use numbers in collecting data, and in providing interpretations of the results

In this study, researchers used a second research design, namely the explanatory sequential mixed methods design. It is chosen as with a quantitative approach, this research requires a number of data in the form of responses from the people of Bandung, especially consumers of traditional West Javanese beverages, so that it allows researchers to get a picture and understand the meaning of the discussed problem. Furthermore, the researcher matched the community's response with the views of the informants with a qualitative approach based on the factual information.

The population in this study were native West Javanese. The target population or the subject of this research are consumers of traditional West Javanese beverages who live in Bandung, West Java.

The sample taken in this study consisted of people who know West Javanese traditional beverages. This sampling must be done in such a way therefore the obtained sample truly describes the actual population or as representative (Sugiyono, 2015).

However, due to the limited research location, the number of respondents cannot be known for sure. Therefore, determining the number of samples can be done by the following Slovin formula:

$$
\begin{gathered}
n=\frac{\mathrm{N}}{1+\mathrm{N}(d)^{2}} \\
\mathrm{n}=\text { sampel, } \mathrm{N}=\text { populasi, } \mathrm{d}=\text { nilai } \\
\text { presisi } 90 \% \text { atau sig }=0,1
\end{gathered}
$$


Calculation:

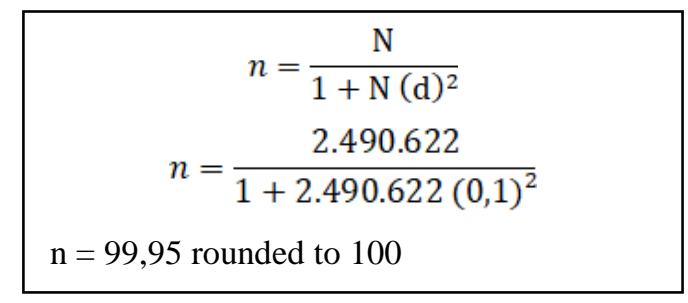

Based on the calculation above, namely 2,490,622, with a sig / error value of $10 \%$ which is converted to 0.1 , the number of respondents that must be obtained is 100 respondents.

\section{Results and Discussion}

This research was conducted from July, $18^{\text {th }} 2020$ to July $28^{\text {th }} 2020$. This questionnaire distribution technique was carried out online using the Google Form application and distributed only to people of Bandung.

In this study, the researchers engage 100 respondents through an accidental sampling technique: engaging the respondents by chance, allowing anybody who wants to participate as long as he/she fulfill the criteria.

\subsection{West Javanese Traditional Beverages that are Familiar to the Respondents}

Before knowing the respondents' perceptions regarding the level of existence of traditional West Javanese beverages in general, the researcher asked several questions to measure the existence level of the traditional West Javanese beverages. The aspects assessed were respondents' experience in consuming the beverages, knowledge about the beverages, access to find the beverages in Bandung, consumption frequency, and public perceptions of Sundanese traditional rice, which is also rare.

Based on the answers of one hundred respondents, the level of existence of each of the traditional West Javanense beverages in Bandung is as follows:
Table 1. Recapitulation of Respondents' Familiarity with Traditional West Javanese Beverages in Bandung (sorted from the highest score to the lowest)

\begin{tabular}{|c|c|c|}
\hline $\begin{array}{c}\text { West Javanese } \\
\text { Traditional } \\
\text { Beverages } \\
\end{array}$ & Frequency & Percentage \\
\hline Es Cingcau & 96 & $94,1 \%$ \\
\hline Bajigur & 94 & $92,2 \%$ \\
\hline Bandrek & 89 & $87,3 \%$ \\
\hline Es Goyobod & 89 & $87,3 \%$ \\
\hline Sakoteng & 87 & $85,3 \%$ \\
\hline Es Serut & 70 & $68,6 \%$ \\
\hline Tjampolay & 70 & $68,6 \%$ \\
\hline Syrup & & \\
\hline Es Peuyeum & 55 & $53,9 \%$ \\
\hline Kalapa Muda & & \\
\hline Lahang & 45 & $44,1 \%$ \\
\hline Es Pala & 23 & $22,5 \%$ \\
\hline Es Cuing & 14 & $13,7 \%$ \\
\hline Es Bojong & 9 & $8,8 \%$ \\
\hline \multicolumn{3}{|c|}{ Source: processed by researchers, 2020} \\
\hline \multicolumn{3}{|c|}{$\begin{array}{l}\text { Table } 1 \text { shows quite diverse } \\
\text { differences. The highest level of existence } \\
\text { of the beverage is es cingcau with a } \\
\text { percentage of } 94.1 \% \text { and the lowest level of } \\
\text { existence is es bojong ice with a percentage } \\
\text { of } 8.8 \% \text {. }\end{array}$} \\
\hline
\end{tabular}

\subsection{Overview of Research Variables}

After analyzing the research data on the existence level of traditional West Javanese beverages in Bandung, the researchers then analyzed the perceptions, knowledge, and understanding of the respondents through a questionnaire described in sub-variables.
a. Recapitulation of Respondents' Response on Knowledge and Consumption Patterns

The following is a recapitulation of respondents' responses to their dietary patterns in consuming traditional beverages as subvariable $\mathrm{X} 1$; 
Table 2. Recapitulation of Respondents' Responses Regarding Knowledge and Patterns of Public Consumption of Traditional West Javanese Beverages

\begin{tabular}{|c|c|c|c|c|c|c|c|}
\hline Comsumption Pattern (X1) & STS & TS & CS & $\mathbf{S}$ & SS & Total & Score \\
\hline $\begin{array}{l}\text { I know all kinds of traditional } \\
\text { West Javanese beverages in } \\
\text { Bandung. }\end{array}$ & 4 & 23 & 37 & 33 & 3 & 100 & 308 \\
\hline $\begin{array}{l}\text { I prefer traditional West Javanese } \\
\text { beverages to other types of } \\
\text { beverages. }\end{array}$ & 2 & 23 & 40 & 29 & 6 & 100 & 314 \\
\hline $\begin{array}{l}\text { I easily found a traditional West } \\
\text { Javanese beverages in Bandung. }\end{array}$ & 0 & 28 & 32 & 35 & 5 & 100 & 317 \\
\hline \multirow[t]{2}{*}{$\begin{array}{l}\text { I find traditional West Javanese } \\
\text { beverages on special occasions } \\
\text { (traditional ceremonies / } \\
\text { thanksgiving / parties, etc.) }\end{array}$} & 0 & 27 & 26 & 38 & 9 & 100 & 329 \\
\hline & Total & & & & & 400 & 1268 \\
\hline
\end{tabular}

Source: data processed by researchers, 2020

The results of data processing in Table 2 for subvariable X1 can be seen through research assessment, the value is then compared with the ideal criteria, which is obtained from the maximum score and the minimum score.

Maximum Index Value:

Highest Score x Number of Questions $\mathrm{x}$ Number of Respondents $(5 \times 4 \times 100=$ 2000)

Minimum Index Value:

Highest Score x Number of Questions x Number of Respondents $(1 \times 4 \times 100=400)$

Interval range (Maximum score-Minimum score):

Interval range in total $(2000-400): 5=$ 320

Based on the results of the data collection scores regarding the subvariable X1, with a total score of 1268 , then 100 respondents can be calculated as follows;

$$
\begin{aligned}
& \text { Respondents } \quad(100): 1268 \\
& 2000 \times 100 \%=63.4 \%
\end{aligned}
$$

From the defined criteria, the continuum line of the community's dietary variables towards the respondent is as follows:

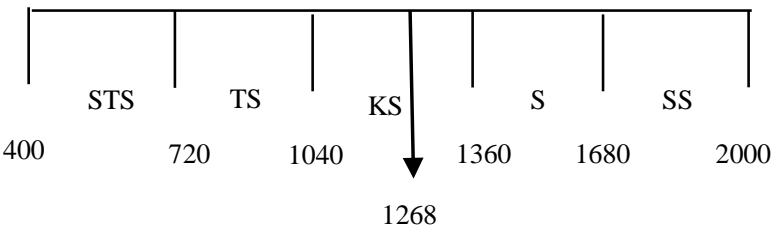

Figure 1. Continuum Line of Public's Knowledge and Consumption Patterns of Traditional West Javanese Beverages

Figure 1 describes the knowledge and consumption patterns of the traditional beverage consumers in Bandung. The continuum line is between the 1040 and 1360 , precisely at 1268 in a "Disagree" category. Meaning that, $63.4 \%$ of the respondents are not familiar with the variety of traditional West Javanese beverages and rarely consume them. This result can also indicate that they prefer modern beverages to the traditional ones.

b. Recapitulation of Respondents on Product Availability

The following is a recapitulation of respondents' responses to the availability of traditional West Javanese beverage products in Bandung as Sub-variable X2; 
Table 3. Recapitulation of Respondents' Responses on the Availability of West Javane Traditional Beverages

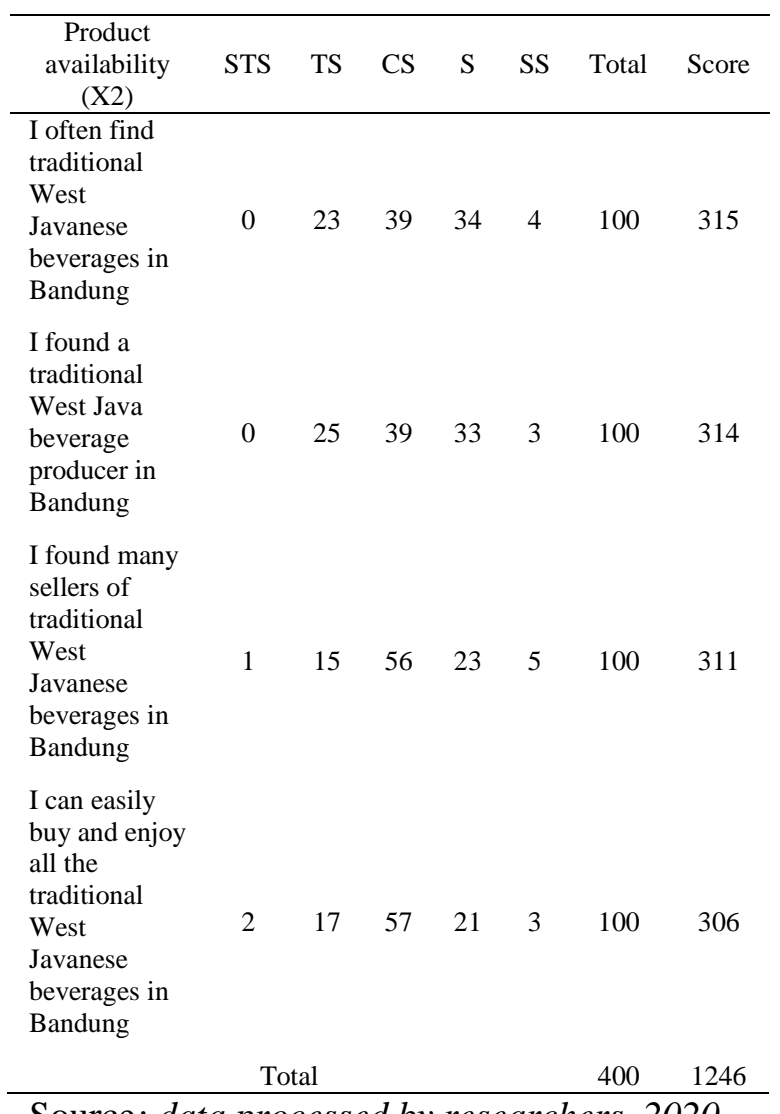

The results of data processing in Table 3 for subvariable $\mathrm{X} 2$ regarding product availability can be seen through research assessments. The scores are compared to the ideal criteria, which are obtained from the maximum score and the minimum score.

Maximum Index Value:

Highest Score x Number of Questions $x$ Number of Respondents $(5 \times 4 \times 100=2000)$

Minimum Index Value:

Highest Score x Number of Questions x Number of Respondents $(1 \times 4 \times 100=400)$

Interval range (Maximum score -Minimum score):

Interval range in total $(2000-400): 5=$ 320

Based on the number of data collection scores regarding the product availability sub-variable (X2), with a total score of 1246 then 100 respondents can be counted as: Respondents (100): 1246 /
$2000 \times 100 \%=62.3 \%$.

From the defined criteria, the continuous line of variable product availability to the respondent is as follows:

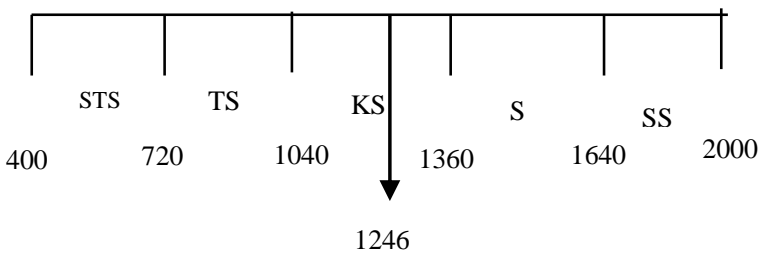

Figure 2. Continuum Line of Product Availability on the Existence of Traditional

West Javanese Beverages in Bandung

Figure 2 describes product availability. The continuum line is between the 1040 and 1360 lines, to be precise at the 1246 line, with the description "Agree". Meaning that, $62.3 \%$ of the total respondents think that it is quite easy to find producers, sellers, and market of traditional West Javanese beverages in Bandung.

\section{c. Recapitulation of Respondents' Responses on Product Marketing}

The following is a recapitulation of respondents' responses to the marketing of traditional West Javanese beverage products in Bandung as subvariable X3;

Table 4. Recapitulation of Respondents' Responses on West Javanese Traditional Beverage Products Marketing in Bandung.

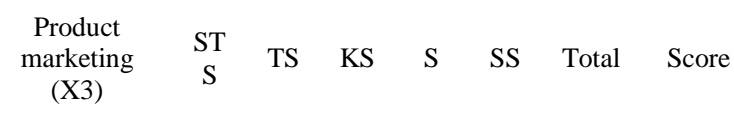

\begin{tabular}{|c|c|c|c|c|c|c|c|}
\hline $\begin{array}{l}\text { I often serve } \\
\text { traditional } \\
\text { West } \\
\text { Javanese } \\
\text { beverages on } \\
\text { special } \\
\text { occasions } \\
\text { (traditional } \\
\text { ceremonies / } \\
\text { thanksgiving } \\
\text { / parties, etc.) }\end{array}$ & 7 & 27 & 39 & 26 & 1 & 100 & 287 \\
\hline $\begin{array}{l}\text { I am } \\
\text { interested in } \\
\text { making and } \\
\text { selling }\end{array}$ & 1 & 17 & 27 & 50 & 5 & 100 & 341 \\
\hline
\end{tabular}




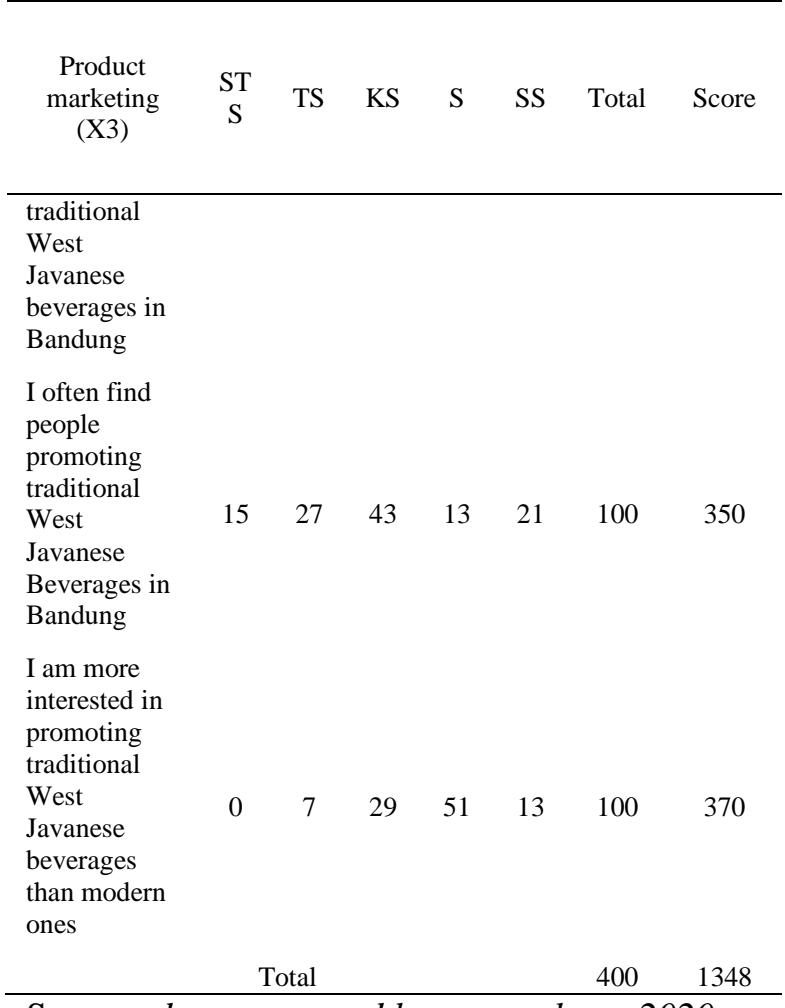

Source: data processed by researchers, 2020

The overall results of data processing on subvariable $\mathrm{X} 3$ regarding product marketing can be seen through the research assessment. The value is compared with the ideal criteria obtained from the maximum score and the minimum score.

Maximum index value $=$ Highest score $\mathrm{x}$ Number of questions $x$ Number of respondents

$(5 \times 4 \times 100=2000)$

Minimum index value $=$ Lowest score $\mathrm{x}$ Number of questions $\mathrm{x}$ Number of respondents

$$
(1 \times 4 \times 100=400)
$$

Interval range (maximum score minimum score): 320

Interval range in total (2000-400) : $5=$

Based on the results of the data collection scores regarding the subvariable X3, with a total score of 1348 , then 100 respondents can be calculated as:

Respondents (100): 1348 / 2000x100\% $=67.4 \%$

From the established criteria, the continuum line of marketing variables for traditional West Javanese beverage products to respondents is as follows:

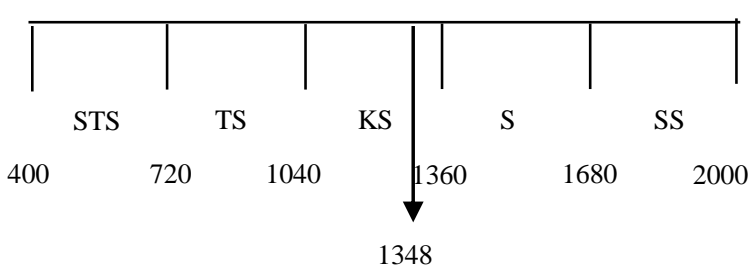

Figure 3. Product Marketing Continuum Line of the Existence of West Javanese Traditional Beverages in Bandung.

Figure 4 describes the marketing of traditional West Javanese beverage products in Bandung. The continuum line is between the 1040 and 1360 lines, to be precise at the 1348, in a "Disagree" category. In other words, $67.4 \%$ of the total respondents stated that it is quite difficult to meet sellers and people who promote West Javanese traditional beverages that it affects consumers' buying interest. Therefore, promotional activities need to be increased, by making the products accessible to consumers who want to buy them. These results also show that respondents are actually interested in promoting the traditional West Javanese beverages. Therefore, the government is expected to support the promotion of traditional West Javanese beverages.

d. Recapitulation of Respondents' Responses on Presentation Time of The Traditional Beverages

The following is a recapitulation of respondents' responses to the serving time of the traditional West Javanese beverages as subvariable $\mathrm{X} 4$;

Table 5. Recapitulation of Respondents' Responses Regarding Serving Time for Traditional West Javanese Beverages

\begin{tabular}{lccccccc}
\hline $\begin{array}{l}\text { Serving Time } \\
(\mathrm{X} 4)\end{array}$ & $\begin{array}{c}\text { ST } \\
\text { S }\end{array}$ & TS & KS & S & SS & Total & $\begin{array}{c}\text { Sko } \\
\text { r }\end{array}$ \\
\hline $\begin{array}{l}\text { I often find } \\
\text { traditional West }\end{array}$ & & & & & & & 340 \\
$\begin{array}{l}\text { Javanese } \\
\text { beverages } \\
\text { based on certain } \\
\text { their serving } \\
\text { times (morning, }\end{array}$ & 0 & 8 & 21 & 47 & 24 & 100 & \\
\hline
\end{tabular}




\begin{tabular}{|c|c|c|c|c|c|c|}
\hline $\begin{array}{l}\text { Serving Time } \\
\text { (X4) }\end{array}$ & $\begin{array}{l}\text { ST } \\
\text { S }\end{array}$ & $\mathrm{KS}$ & $\bar{S}$ & SS & Total & $\begin{array}{c}\text { Sko } \\
\text { r }\end{array}$ \\
\hline \multicolumn{7}{|l|}{$\begin{array}{l}\text { afternoon, } \\
\text { evening) }\end{array}$} \\
\hline & Total & & & & 100 & 340 \\
\hline
\end{tabular}

Source: data processed by researchers 2020

The overall results of data processing on subvariable $\mathrm{X} 4$, regarding the serving time of the beverages can be seen through the research assessments. The score is compared with the ideal criteria obtained from the maximum score and the minimum score.

Maximum index value:

Highest score $\mathrm{x}$ Number of questions $(5 \times 1 \times 100=500)$

Minimum index value:

Lowest score $\mathrm{x}$ Number of questions $(1 \times 1 \times 100=100)$

Interval range (Maximum score Minimum score):

Based on the results of the data collection scores regarding the subvariable $\mathrm{X} 4$, then with 100 respondents, it can be calculated as follow:

Respondents (100): $340 / 500 \times 100 \%=68 \%$

From the defined criteria, the variable line of time to serve traditional West Javanese beverages to the respondent is as the following:

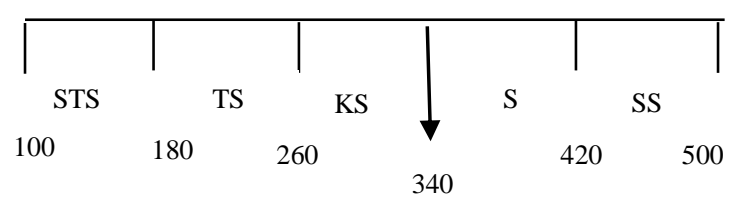

Figure 4. The Continuum Line of Serving Time on the Existence of Traditional West Javanese Beverages in Bandung

Figure 4 describes the existence of traditional West Javanese beverages based on serving time at certain times (morning, afternoon, evening). The continuum line points 340 with the caption "Disagree". This means that $68 \%$ of respondents disagree that traditional West Javanese beverages are served at a certain time.

e. Recapitulation of Respondents on the Existence of Traditional West Javanese Beverages in Bandung

Based on previous literature studies that have been presented, there are 4 sub-variables to the variable $(\mathrm{X})$, namely the existence of traditional beverages. Therefore, conclusions are obtained through descriptive analysis techniques, namely by finding the maximum and minimum scores, as well as the interval class as follows:

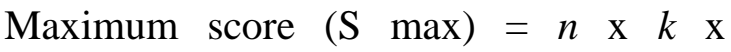
Maximum value

Minimum score (S min) $\quad=n \begin{array}{llll} & \mathrm{x} & k & \mathrm{x}\end{array}$ Minimum value

$$
\begin{aligned}
& \text { Interval Class (c) } \\
& \quad \text { - Description: } \\
& \mathrm{n}=100 \text { respondents } \\
& \text { Maximum value }=5 \\
& \mathrm{k}=5 \quad \text { Minimal } \quad \text { Value }=1
\end{aligned}
$$

Therefore:

Maximal Score $=100 \times 13 \times 5=6500$

Minimal Score $=100 \times 13 \times 1=1300$

Interval Class $=(6500-1300): 5=1040$

In the calculation of the interval class above, it can be explained that the existence of traditional West Javanese beverages, according to consumers, can be seen in the following table:

Table 6. Recapitulation of Respondents regarding the Existence of Traditional West Javanese Beverages in Bandung

\begin{tabular}{lc}
\hline \multicolumn{1}{c}{$\begin{array}{c}\text { The Existence of West Javanese } \\
\text { Traditional Beverages (X) }\end{array}$} & Score \\
\hline Public's Knowledge and & 1268 \\
Consumption Patterns (X1) & \\
Product Availability (X2) & 1246 \\
Product Marketing (X3) & 1348 \\
Serving Time (X4) & 340 \\
\multicolumn{1}{c}{ Total } & 4202 \\
\hline
\end{tabular}

Source: data processed by researchers, 2020

Percentage of respondents' scores $(100)=$ $(4202 / 6500) \times 100 \%=64,64 \%$ or $65 \%$

Table 6 shows the results of the accumulated questionnaire data of variable $\mathrm{X}$ on the existence of traditional West Javanese beverages as Sundanese cultural heritage, according to consumers, are 4202. Next, the interval class calculations is completed to determine whether or not the 
existence level is good.

Table 7. Interval Class of West Javanese Traditional Beverages Existence in Bandung

\begin{tabular}{cc}
\hline Score & Descriptions \\
\hline $1300-2340$ & Not Very Good \\
$2341-3380$ & Not Good \\
$3381-4420$ & Quite Good \\
$4421-5460$ & Good \\
$5461-6500$ & Very Good \\
\hline
\end{tabular}

Source: data processed by researchers, 2020

Table 7 shows the accumulation results of the questionnaire. The score reaches 4202, which means that this interval class line is between $3381-4420$ or in the "Quite Good" category.

\subsection{Interview Results with the Informants}

\subsubsection{Informant Biodata}

Researchers have collected the data for 10 days from 18 July 2020-28 July 2020. The data was obtained from the results of distributing questionnaires containing consumer responses on the existence of traditional West Javanese beverages in Bandung.

After the questionnaire data were obtained, the researchers conducted interviews to obtain descriptive data, from informants with different backgrounds, namely producers, ICA members, and the chairman of the West Java Restaurant Association. The interview was intended to find answers from the problem discussed, as well as to find strategies and solutions to maintain the existence of traditional West Javanese beverages in Bandung as a Sundanese cultural heritage.

Interviews were conducted directly and indirectly. Direct face-to-face interviews are carried out by visiting the informants. Indirect interviews are carried out online through WhatsApp video calls.

The following is the biodata of the informants:
Table 8. Informant Biodata

\begin{tabular}{|c|c|c|c|}
\hline No & $\begin{array}{l}\text { Interview } \\
\text { date }\end{array}$ & Name & Occupation \\
\hline 1 & $\begin{array}{c}\text { Wednesday, } \\
\text { July } 22, \\
2020\end{array}$ & Deni & $\begin{array}{l}\text { Traditional } \\
\text { Beverage } \\
\text { Entrepreneur }\end{array}$ \\
\hline 2 & $\begin{array}{l}\text { Wednesday, } \\
\text { July } 22 \text {, } \\
2020\end{array}$ & Uum & $\begin{array}{l}\text { Traditional } \\
\text { Beverage } \\
\text { Entrepreneur }\end{array}$ \\
\hline 3 & $\begin{array}{l}\text { Thursday, } \\
\text { July 23, } \\
2020\end{array}$ & Adi & $\begin{array}{c}\text { Chef and } \\
\text { member of ICA }\end{array}$ \\
\hline 4 & $\begin{array}{l}\text { Monday, } \\
\text { July 27, } \\
2020\end{array}$ & Iman & $\begin{array}{c}\text { Chef and } \\
\text { member of ICA }\end{array}$ \\
\hline 5 & $\begin{array}{l}\text { Thursday, } \\
\text { July 30, } \\
2020\end{array}$ & $\begin{array}{c}\text { Dedie } \\
\text { Soekartin }\end{array}$ & $\begin{array}{c}\text { Chairman of the } \\
\text { West Java } \\
\text { Restaurant } \\
\text { Association }\end{array}$ \\
\hline
\end{tabular}

Based on the results of the interviews, it can be said that the existence of traditional West Javanese beverages in Bandung is still maintained, and can survive in West Java. Although several types of traditional West Javanese beverages are only available in their home area or outside Bandung, these traditional beverages, can be said, to still exist in their hometown.

People's interest in traditional West Javanese Beverages is still fairly good, indicated by their purchase frequency. Modern beverages which are currently becoming a trend only fulfilling people's curiosity, and usually do not last long. Contrary to the traditional West Javanese beverages which are still in demand especially among adults or the elderly.

The excellence of this traditional West Javanese beverages lies in thier rich taste of spices, authenticity of taste, balanced blend of flavors, and simple appearance. Although there are several beverages that are similar and have almost the same composition each traditional West Javanese beverages has unique characteristics, therefore the producers should pay attention to the consistency of the taste, making process, and the quality of taste. 
The challenges faced by producers are consumer interest, namely the beverage enthusiasts are still dominated by adults or the elderly. The emergence of several types of modern drinks, such as Thai tea, boba milk tea, etc., has made the younger generation, who in general always want to try new things, prefer to buy modern drinks rather than the traditional ones. Furthermore, the availability of raw materials is also an obstacle in selling the traditional beverages according to producers. According to the experts, the challenge in maintaining the existence of traditional beverages is the minimum effort of the the government and food experts in the promotion.

The promotion strategy carried out by producers varies according to the size of their business scale. Street vendors, who are both producers and sellers, carry out a promotional strategy by inviting some of their friends to join in selling traditional beverages, with the aim of preserving them. Meanwhile, producers who have medium-sized businesses, such as those who own kiosks or cafes, are aware of technological advances and sell their products online through various social media as promotional media. Another promotional strategy carried out by medium-scale businesses is by changing the packaging from plastic to bottle to make them easier to carry anywhere.

The promotion strategy suggested by experts is to introduce traditional West Javanese beverages through learnings such as at schools or universities. Knowledge of traditional/regional food and beverages need to be included in the curriculum or teaching materials. Currently, according to the experts, the sense of belonging and loving of local products in the younger generation has decreased, when in fact; they have the potential to promote the West Javanese traditional beverages. Beside that, promotional activities carried out by the government are also highly expected, so that traditional West Javanese beverages can be widely known.

Developing the attitude of loving the local culture can also be a solution to preserve and maintain the existence of the traditional West Javanese beverages. It can be done by getting used to consuming traditional foods and beverages. As for the producers, it is suggested that they keep the consistency in selling despite the change of beverage trends. The producers and sellers must maintain the traditional West Javanese beverage business with the aim of preserving them. The government must be more proactive in promoting the traditional beverages and simplifying the bureaucracy for those who intend to start business in traditional beverages.

Based on the data obtained from interviews, the existence of traditional West Javanese beverages is still lacking among the people of Bandung. People's consumption and knowledge about the beverages is still poor. The majority of Bandung people are still unfamiliar with, and have never consumed all types of traditional West Javanese beverages because some are only available or only sold in their home areas.

Researchers also conducted in-depth interviews to get descriptive results and in accordance with the circumstances, with several selected sources, namely from the producers, sellers, and experts. Time has change, and it leads to the emergence of modern or non-traditional beverage trends. According to the experts, it is an inevitable and temporary phenomenon due to their popularity's fluctuation. As for the traditional West Javanese beverages, even though their existence is not that noticeable, their existence will always last as they have loyal connoisseurs. The love for traditional beverages among the younger generation also needs to be increased to preserve the traditional beverages themselves. 


\section{Conclusions and Suggestions}

\subsection{Conclusions}

Based on the data findings and discussion in the previous chapter, it can be concluded as follows:

Referring to the continuum line, it can be inferred that the existence of West Javanese traditional beverages in terms of people's knowledge and consumption, product availability, product marketing and serving time are in the poor category.

The results of the analysis based on the data obtained from the respondents, sorted from the most popular to the less popular in Bandung are es cingcau, bajigur, bandrek, es goyobod, sakoteng, es serut, tjampolay syrup, es peuyeum, lahang, es pala, es cuing, and es bojong. The types of beverages that still need to be improved are lahang, es pala and es bojong.

It can be concluded that, according the informants, that the existence of traditional West Javanese beverage may not as popular as they are in the past. However, they still exist and has loyal connoisseurs. Promotional activities are arguably still lacking. The producers and sellers still sell their products conventionally; through street vendors, stalls or kiosks selling. The producers and sellers expect that people will continue to learn about the variety of traditional West Javanese beverages, and introduce them to the younger generation to avoid extinction of the products. The producers and sellers also hope that there is a central place to sell the products. In addition, the government is expected to actively hold bazaars, festivals and exhibitions about traditional West Javanese beverages.

\subsection{Suggestions}

Based on the results of research and observations through the questionnaire method, direct interviews, and online interviews, several suggestions are offered as the following:
Educational institutions are expected to educate the younger generation about a sense of belonging and love for Indonesian products, and participate in preserving local culture, especially in the culinary field so that traditional beverages can preserved.

The Government of Bandung, especially the Culture and Tourism Departement, is expected to increase festivals, exhibitions, or traditional beverages bazaars on a regular basis or periodically in order to raise public interest in West Javanese traditional beverages as well as introduce their variations. In addition, the government should actively promote traditional West Javanese beverages both domestically and internationally, so that the beverages can be known and enjoyed worldwide. The producers are also expected to maintain the quality and authenticity of the taste of the product to sustain the consumers' loyalty. In addition, promotional activities through online social media need to be improved.

West Javanese traditional beverages sellers are expected to increase sales competitiveness with non-traditional beverages by aggressively promoting them online such as on social media, print media, or directly to consumers, so that people are interested again in getting to know and consuming traditional West Javanese beverages.

Restaurants and cafes in Bandung are expected to include traditional beverages in their menu list to introduce them to teenage consumers.

Hopefully this research can provide useful information and be a reference in improving the existence of traditional West Javanese beverages as Sundanese cultural heritage Bandung. For further research, it is expected that more sources and references related to the traditional West Javanese beverages are included for a better literature. 


\section{References}

Arikunto, S. (2002). Produser penelitian suatu pendekatan praktek. Jakarta: PT. Rineka Cipta.

Sugiyono. (2015). Metode Penelitian Kuantitatif dan Kualitatif R\&D. Alfabeta

Syafiie, Kencana. 2009. Pengantar Ilmu Pariwisata. Mandar Maju, Bandung

Ekadjati, E. (1993). Kebudayaan Sunda, Suatu Pendekatan Sejarah Jilid 1. Jakarta : Pustaka Jaya.

Ekawatiningsih. (2008). Minuman Tradisional, Bandung: Alfabeta

Hufad, M. (2005). Karakteristik Budaya Sunda, Bandung: Alfabeta

Huzeiker., Kraft., Joko. (1994). Pengantar Ilmu Pariwisata. Penerbit: Andi Yogyakarta

Kalsum, K. (2010). Kearifan Lokal dalam Wawacan Sulanjana: Tradisi Menghormati Padi pada Masyarakat Sunda di Jawa Barat, Indonesia. SOSIOHUMANIKA, 3(1)

Kerly, G. (2018). Eksistensi Kuliner Tinutuan Dalam Pola Kebiasaan Makan di Kota Manado.

Kotler, P. (2005). Las preguntas más frecuentes sobre marketing. Editorial Norma,

Koentjaraningrat. (1980). Metode Wawancara, dalam Koentjaraningrat, Metode-Metode Penelitiaan, Jakarta. PT: Gramedia

Long, L. M. (Ed.). (2004). Culinary tourism. University Press of Kentucky
Marsum, w, (2004). Bar, Minuman dan Pelayanannya, Yogyakarta: Andi Offset

Ningsih, Caria (2020), Pelestarian dan Pengembangan Kampung Nikmat Cigugurgirang sebagai Destinasi Wisata Warisan Budaya Gastronomi Sunda. Tourism Scientific Journal Vol.5 No.2, hlm 265-275 http://www.jurnal.stiepar.ac.id/index. $\mathrm{php} / \mathrm{tsj} /$ article/view/97

Notoatmodjo, S. (2007). Perilaku kesehatan dan ilmu perilaku. Jakarta: Rineka Cipta

Sunaryo, E. S. (2015). Minuman Tradisional Penguat Kekebalan Tubuh, Jakarta: PT. Alex Media Komputindo

Suwantoro, Gamal. (2004). Dasar-dasar pariwisata. Penerbit: Andi Yogyakarta

Suharyono \& Amien, M. (2013). Pengantar Filsafat Geografi. Yogyakarta: Ombak.

Taqwani, D. M. (2012). a- research.upi.edu. Analisis Kebudayaan Gastronomi Dan Tindak Tutur Dalam Kajian Pragmatik Pada Film Ratatouille, 55

Turgarini, Dewi. (2018). Gastronomi Sunda Sebagai Daya Tarik Wisata Kota Bandung. Universitas Gadjah Mada,

Yoeti, Oka A. (1996). Pengantar Ilmu Pariwisata. Bandung: Angkasa

Zaprulkhan. 2012. Memahami AnarkismeSosial dalam http://cetak.bangkapos.com/opini/rea d/1224.html. Diakses 13 April 2020 